Published in Mediterranean Historical Review 33 (2018), pp. 89-110

\title{
Memorial Soliloquies in Post-Colonial Rhodes and the Ghost of Mediterranean
}

\section{Cosmopolitanism}

\begin{abstract}
Alexis Rappas
\section{Introduction}

Rhodes, the main island of the Dodecanese Archipelago in the Aegean Sea, has long been one of Greece's most prized touristic destinations. Direct flights operated by 61 airline companies fly over 1.5 million tourists yearly from more than one hundred European and Mediterranean cities to Diagoras International airport. ${ }^{1}$ These staggering figures are the result of a successful marketing of the island as a perfect location for "creative holidays." Along with its beautiful long beaches and picturesque villages, Rhodes' venerable history -illustrated by numerous Ancient Greek ruins, Frankish buildings, Ottoman mosques and Italian colonial constructions ${ }^{2}$ - is indeed being promoted to make the island the archetype of a modern tourist resort, both relaxing and intellectually rewarding. In the process, Rhodes' diverse heritage, especially visible in the old Medieval Town -a UNESCO World Cultural Heritage site since $1988^{3}$ - is thus reified and repackaged into an atemporal Levantine cosmopolitanism palatable to global tourists. Yet this depiction of the island as 'multicultural', a crossroad where civilizations blend effortlessly, conceals the violent historical processes which transformed it into a uniformly Greek province.
\end{abstract}

On closer inspection, the island is full of traces which tell of different, more exclusive, and fragmented stories. The streets of the northwestern tip of the island's capital bear the resounding names of the most celebrated heroes in Greek national history. A few hundred meters 
east, inside the Old Town, stands a Holocaust memorial to the 1604 Rhodian Jewish (Rodesli ${ }^{5}$ ) victims of the Nazis. ${ }^{6}$ The precarious presence of a Muslim community in Rhodes is reminded by a couple of discreet, functioning mosques inside the Old Town -different from the Ottoman ones which are now monuments- and, outside the Old Town, the battered four hundred year-old Murat Reis Ottoman cemetery. Notwithstanding the geographical proximity of the physical traces of a past shared between Christians, Muslims and Jews, written accounts focusing on the modern history of the island's three communities and their relations with one another are nearly inexistent. $^{7}$ Instead, history books produced locally or testimonies of actors of the time including Holocaust survivors- make only transient, and rarely favorable, allusions to intercommunal relations.

This paper is based on a close reading of Greek and Rodesli narratives: historical studies, memoirs and works straddling these writing conventions. It will focus on evocations of the time when Rhodes and the Dodecanese were under Italian (1912-1943) and then German (1943-1945) rule, the last periods when the three religious communities - Christian, Muslim and Jewishcoexisted. For reasons which will be developed in the first part of this paper, there are virtually no comparable narratives emanating from the Dodecanesian Muslim community. Exploring, then, the dissonance between Greek and Rodesli narratives, this article seeks to unearth the rationales at work into these parallel spatial inscriptions of memory. Greek narratives firmly anchor Rhodes into the periphery of the Greek national space of which the island becomes a frontier. Jewish testimonies by contrast recreate the Djuderia -the old Jewish neighborhood in the island's capital- as a specific place, excised from its immediate insular setting and operating as the core of a transnational Rodesli diasporic network. Notably, the competing spatial configurations into which Greek and Rodesli narratives relocate Rhodes are never, properly 
speaking, "insular," perhaps the only conceivably intercommunal geography. The term "soliloquies" is here proposed to account for the absence of cross-references or conversations between Greek and Rodesli texts. Naturally the analysis could have been enriched with the inclusion of oral testimonies. This, however, was made difficult by the fact that there are only few surviving actors of the period under scrutiny, dispersed, what is more, in many different countries. In addition, the handful of testimonies collected from Greek descendants of actors of the time reveal a striking compatibility with the written sources which most likely informed them.

The article concedes that this mutual neglect between these written sources partly derives from the different perspectives from which these texts were produced: Greek narratives were written from within the national space in which the islands were politically integrated in 1947 and serve to vindicate centuries of resistance against the "dehellenizing" proclivities of their successive rulers; Rodesli narratives, on the other hand, are exilic texts written from the various locations in which survivor Rhodian Jews and their descendants settled before and after the Holocaust and aim at preserving the cultural identity of a physically destroyed community. Yet aside from the specific circumstances of Rhodes' history, the article argues that the soliloquies observed in the cases under scrutiny may be revealing of a larger problem besetting research on interethnic relations in the Eastern Mediterranean shortly before and after the fall of the Ottoman Empire. Indeed scholars have noted that historians have been facing a structural difficulty in seeking to narrate pre-national interethnic and interreligious coexistence in the Eastern Mediterranean beyond the nostalgic mode. ${ }^{9}$ A major reason for this, this article argues, is that such coexistence has been apprehended through the prism of informal or semi-formal sociability -from the coffeehouse to the chamber of commerce- but often disconnected from its economic 
base. Engaging a dialogue with the historiographies of other post-Ottoman, erstwhile multicultural settings, the article draws attention to property and more specifically to how cultural (and sometimes legal) censorship over any discussion of property redistribution across cultural lines at the time of nationalization of the Eastern Mediterranean profoundly distorted conceptualizations of pre-national "cosmopolitan communities."

Moving beyond the circumstances of the production of local texts and testimonies, this paper then enjoins to take their content seriously and inquire into the extent to which their reciprocal indifference and communal -as opposed to intercommunal- dimension impel us to acknowledge the limits and the brittleness of "multiculturalism" in the pre-national Eastern Mediterranean: Does this seeming inability or unwillingness to "remember together" tell us something about intercommunal relations before and beyond the trauma of separation? To the degree that it enables us to open this discussion, Rhodes can be considered as highly emblematic of the broader history of the region where the dynamics of colonialism, nationalism and ethnic cleansing intersect; perhaps more than other post-Ottoman setting it is also a concrete site where different memorial traditions -nationalistic, Holocaust, post-colonial- align, compete and collide. ${ }^{10}$ In investigating these discursive encounters, strategic avoidances, selective amnesias, and the different notions of "space" and identity emerging therefrom, the theoretical ambition of this paper is to reexamine from the angle of memory the notion of "cosmopolitanism" which has been so central to studies of the late $19^{\text {th }}$ and early $20^{\text {th }}$ century Eastern Mediterranean.

A final remark concerns the organization of this paper. A first section offers an overview of the Christian, Muslim and Jewish communities in the Dodecanese roughly from the end of the nineteenth century to nowadays. The second and third sections examine alternately the Greek narratives and Rodesli testimonies with a focus on the frequency and nature of cross-communal 
references. The fourth and final section brings this analysis to bear on our understanding of prenational Mediterranean "cosmopolitanism." It could be argued that the treatment of Greek and Rodesli texts in two separate sections reproduces and validates the aforementioned separation of memories along communal lines. To this must be countered, again, that the major point of this article, developed in the final section, is not to create artificial intercommunal bridges between obstinately soliloquous narratives; but rather to take stock of their univocal nature and perhaps imagine ways to still use them in the reconstitution of a culturally diverse past.

\section{The communities and their relations}

In Rhodes as in much of the Eastern Mediterranean the notion of 'community' has often been associated with Ottoman forms of governance based on a delegation of certain fiscal and administrative powers to the leaders of non-Muslim and therefore subject religious communities (Christian and Jewish mainly). This imperial system of governance was terminated under the Young Turks in 1908 while the Greek-Turkish war and the 1923 exchange of populations brought to an end the coexistence of different religious groups in the region, essentially Christian-Orthodox and Muslim. Cyprus and Rhodes have temporarily constituted exceptions in this "unmixing of peoples," namely the twin processes of demographic engineering and national homogenization which marked the Eastern Mediterranean. ${ }^{12}$ In both cases colonial rule -British in Cyprus, Italian in Rhodes- refrigerated, at the same as it altered the nature of, the religious plurality of these insular societies. ${ }^{13}$ Nowadays there are no officially recognized 'communities' in Rhodes. Aside from a growing number of migrants, all of the island's 117,000 permanent inhabitants are Greek citizens and, in their overwhelming majority, of Greek-Orthodox faith. Around 3000-3500 Muslim Greek citizens inhabit the Old Medieval Town as well as a number 
of villages in the North and the South of the island. ${ }^{14}$ Under the February 1947 treaty of peace between Italy, Greece and the Allied Powers, which organized, among other things, the transfer of Rhodes and the Dodecanesian islands to Greece, all of these Muslims became Greek citizens. Although socially and economically well-integrated, Rhodian Muslims have been threatened in the past with "large-scale expulsion and expropriation" at the time of Greek-Turkish crises, most notably related to the Cyprus conflict in 1955 and 1974. In 1972, the Greek military junta shut down the Turkish-language primary schools in Rhodes in retaliation for the ill-treatment of the Greek minorities by the Turkish government on the islands of Imbros (Gökçeada) and Tenedos (Bozcaada). ${ }^{17}$ This context has led many Muslim Rhodians to lead what Kira Kaurinkoski has called "transnational livelihoods," maintaining social, economic and private connections between Rhodes and Turkey. ${ }^{18}$ Because of these conditions, Rhodian Muslims are also not making any public claims to cultural specificity and will assert their Greekness to anyone inquiring into the affairs of their community; there exists to the knowledge of this author two books, in Turkish and published in Turkey, dealing specifically with the Muslims of Rhodes in the twentieth century, among which only one is penned by a Rhodian. ${ }^{19}$

Before the Second World War, a Sephardic, Ladino-speaking community numbering around 2000 people lived in the eastern quarter of the Old Town known as La Djuderia. Discriminated against after Italian authorities implemented the provvedimenti per la difesa della razza in Rhodes in November 1938, it has been almost entirely annihilated by the Nazis after they took over control of the Dodecanesian islands, following the fall of fascist Italy in September 1943. Deported in July 1944, Rodeslis were among the last European Jews sent to the death camps. In 2010, only two Rodesli families still lived in the island. ${ }^{20}$ Most Greek Jews now living in Rhodes are not originated from the island but from different parts of Greece. They are 
too few to form a minyan quorum of ten Jewish adults required for the regular holding of public prayers. Consequently, in spite of its name, what is known as the Jewish Community of Rhodes, responsible for the maintenance of the island's Synagogue, Jewish cemetery, Holocaust memorial and museum, mainly consists of an administrator detached from and directly accountable to, the Central Board of Jewish Communities in Greece.

\section{Greek historiography and national appropriation}

Most narratives on Rhodes and the Dodecanese under Italian rule are authored by local, mainly amateur Greek historians. This literature is overabundant and in Rhodes at least constitutes the hegemonic discourse. I will focus here on what may be considered the three most influential works, selected according to an increasing degree of distance to the narrated events.

As Rhodes' Greek-Orthodox Bishop (1913-1946), Apostolos Tryfonos was a key, if controversial, actor during the years in which the Dodecanese was an Italian Possedimento. Throughout his two-volume Memoirs, $B$ which were published in $1947^{22}$, the bishop strives to impersonate a somewhat conventional iteration of a pivotal character in modern Greek nationalistic history, that of the ethnarch of the Orthodox Dodecanesians, acting as their diplomatically-savvy representative and intermediary with the state working underhand to safeguard their religion and language. ${ }^{23}$ In their five-hundred pages the bishop's memoirs make scant reference to the other religious communities of the Dodecanese. Writing as an Orthodox cleric -one eager to disprove his alleged collusion with state authorities- it is not surprising that Apostolos would reserve his most vitriolic comments to Catholics and their state-supported proselytizing, ${ }^{25}$ and among them, to the "Franco-Levantines," namely alleged descendants of families said to originate in one of the Italian Merchant Republics . More intriguing is the 
bishop's treatment of the Jewish community. Late in the first volume, allusion is made to the 1938 anti-Semitic laws although the bishop hastens to add that "[i]n spite of all this, the Jews did not stop being the Italians' beloved children and not a single Jew was persecuted or ill-treated (...)." ${ }^{26}$ Rodeslis reappear in the second volume of the memoirs in the context of the Nazi occupation of the island. After describing the 20 July 1944 round-up of Jews by Germans, the bishop goes on to write:

While all of us [Dodecanesians], including the producers, were deprived even of rye bread, flour (even white flour), rice, sugar, a number of different types of pasta and other types of food were found in great quantities in the houses of Jews. Mittino's [the head of the police] infamous police showed no shame for all this because they would take their share and maybe, maybe... the lion share !! [sic $]^{27}$

In this passage, while Rodeslis are depicted as hoarders during times of scarcity, there also seems to be a complaint that the Italian police did not share the spoils of the Jewish homes with the wider population but instead kept them for themselves.

Apostolos' memoirs became the matrix which informed most Greek studies of that period. Among the more scientifically-inclined writings, Christodoulos I. Papachristodoulou's 1972 History of Rhodes can be considered to be a seminal and transitional text. ${ }^{28}$ Because of the 50-year rule, Papachristodoulou could not draw on official archives and therefore relied essentially on his own reminiscences as a schoolteacher for the section of his book dedicated to the Italo-German occupation of the Dodecanese (1912-1945). ${ }^{29}$ Like Bishop Apostolos then, Papachristodoulou is a witness of the time; unlike the cleric however, his own involvement into the narrative is practically effaced. This text is indeed a testimony of a different kind aiming to substantiate the Hellenic essence of Rhodes and the Dodecanese. Aside from the teleological 
chronology adopted in the full title -the end of this story is the island's incorporation to Greeceseveral narrative devices are used to firmly anchor the Dodecanese within a Hellenic historical continuum. These include reserving the expressions "Dodecanesians" and "Dodecanesian people" to refer exclusively to the Greek-Orthodox islanders -Muslims being designated as "Turks" while Rodeslis simply as "Jews"- and representing Rhodian history under the Italian and German occupations as one of unanimous and consistent "struggle" for national rehabilitation. In a passage dedicated to the echo of the Greek military successes of 1940-1941 on the Albanian front, Papachristodoulou thus writes:

[F]rom hour to hour [Dodecanesians] wait for the mighty outbreak, not with fear, but with anger, a feeling which thrusts them towards the great struggle from which they will emerge victorious or in which they will be annihilated. Italy's attitude in the Dodecanese, the provocations and the humiliations endured by the entire nation awakened the Panhellenic feeling of our people, who had waited for an opportunity to avenge themselves. ${ }^{30}$

In the narration of that patriotic struggle, we find the same motifs and milestones which punctuated Bishop Apostolos' memoirs. These include the early resistance movements, the divisive question of the Autocephaly, ${ }^{31}$ and the staunch resistance against the different stratagems imagined by Italian authorities to Italianize the Archipelago. ${ }^{32}$ In contrast to Bishop Apostolos, Papachristodoulou does refer to the deportation of Rhodian Jews by the Nazis as an "inhuman measure, which will haunt forever its perpetrators and the entire humanity which despite all of its civilization did not manage to elevate itself above its primitive condition and ferocious instincts [illustrated by] the extermination of innocent existences." ${ }^{34}$ Previous references to Rodeslis however use and reactivate familiar anti-Semitic tropes. Regarding the 
Rodeslis' own culture, he thus states that from the moment Italians occupied the Dodecanese, the Jews "abolished the Spanish [Ladino] language in their schools and adopted instead the Italian, without this bothering them in any way since both [languages] were foreign to them and renamed their schools 'Scuole Israelitiche Italiane'.. 35 The reference to Rodeslis' alleged indifference to their native language is of course a not too subtle iteration of the "wandering Jew" trope.

Zacharias Tsirpanlis is probably the most academically-sound of all Greek nationalist historians of the Dodecanese; a trained, professional historian, Tsirpanlis is perfectly up-to-date with all scientifically-inclined publications touching on the Dodecanese as attested by the lengthy annotated bibliography he wrote for the second edition of Papachristodoulou's History of Rhodes. ${ }^{36}$ His book, Italocracy in the Dodecanese, 1912-1943: Alienation of Man and of the Environment is a rigorously documented account of Italian rule in the Archipelago, ${ }^{37}$ drawing extensively on official archives, both Greek and Italian. Yet while this work has all the trappings of a scientific inquiry, including the numerous references and the dispassionate tone, the structural elements present in the two previously examined books remain in place: the metanarrative of a unanimous Dodecanesian struggle for enosis (or the political union with Greece) drives the text with the now usual motifs of the repeated and multifarious attempts of Italians to dehellenize the islands. Other religious communities do not fare much better than in Bishop Apostolos' memoirs or Papachristodoulou's History of Rhodes. Exactly seven pages are devoted to them in a study of over 400 pages; their treatment in a separate section further underscores their extraneity to the Archipelago. ${ }^{38}$ In this regard, the fact that the period covered in the book ends in 1943 is revealing. Technically Italocracy, namely the direct rule of the Dodecanese by fascist Italy, did indeed end in 1943 when control over the Archipelago was taken over by Nazi Germany. Yet the entire administration was still staffed by Italian officials 
even if they worked under German supervision. By ending his study in 1943, Tsirpanlis leaves outside of the scope of his inquiry the deportation of the Jews barely a year later, arguably the event which most contributed to the "transformation" of the "[Dodecanesian] environment." Of course the transformation Tsirpanlis is concerned with is that of Greek minds, and in this regard the very term Italokratia inserts the Archipelago into a continuum of Greek resistance against the different foreign occupations -xenokraties- which sought to alter the Hellenic cultural and religious fabric of the various constituent parts of contemporary Greece. ${ }^{39}$

These three narratives, the memoirs of an actor of the time, a historical analysis partly based on the testimony of an actor of the time and an inquiry by a professional historian, form part of a Greek textual production, or discourse, built around one same metanarrative, that of Greek cultural resilience in the face of successive foreign occupations. To an extent this is, of course, a local variation on the central motif of Greek national history as written since the $19^{\text {th }}$ century, stipulating the direct civilizational continuity between Ancient and Modern Greece through Byzantium, the resilience and eventual rebirth -or palingenesis- of the Hellenic national spirit: ${ }^{41}$ : to paraphrase Nicholas Doumanis and Nicholas Pappas, "Grand History" does happen in a "Small Place" like Rhodes. ${ }^{42}$ Such nationalistic readings of the history of Rhodes are not, however, part of an organized propaganda offensive. It is a more structural phenomenon, drawing on a "tradition of knowledge that is presented as the truth"43 and which is constantly promoted through state institutions, particularly in the highly centralized Greek state schools. ${ }^{44}$ Aimed at reinforcing and diffusing a national sense of belonging, the understanding of Greekness this tradition of knowledge conveys is deliberately abstract and therefore not subject to change, relying on what Efi Avdela termed an "awareness of Hellenic continuity." 45 This episteme has inflected history-writing in a seemingly paradoxical way. While most of the writers under 
scrutiny in this paper make strong claims to scientificity, they simultaneously perceive their inquiry as an act of justice by unearthing and reorganizing the past in order to make it compatible with a predefined regime of truth. They are thus recorders and custodians of what, in the past, serves to delineate the contours of, and reinforce the allegiance to, the national community.

While these observations could be made about any history adopting the nation as its conceptual framework, in Rhodes they possess a specific salience. Written by amateur and professional historians with strong family ties in the Dodecanese, these histories have a clear anti-colonial purpose. Their goal is to overturn 30 years of Italian colonial rule marked by a welldocumented and concerted policy of cultural engineering and dehellenization based on the Italianization of the minds and large-scale expropriation of lands. This task appears all the more urgent to these historians as Rhodes and the Dodecanese were the last territory incorporated to Greece in 1947, a territory what is more, causing geopolitical anxieties lying so close to the shores of Turkey. ${ }^{47}$ Indeed claims about what constitutes the national community are often interconnected with and, in Rhodes indistinguishable from, claims about rightful occupation of space. Thus in the literature reviewed here, one will regularly encounter semantic slippages where the islands are used as a metaphor for Dodecanesian Greeks and vice-versa, a telling illustration of a claim to autochthony. But to the extent that Greekness is, as mentioned earlier, defined in abstract and essentialist terms, it conveys an exclusionary logic about who is naturally endowed with the right to live in Rhodes.

Uneasily poised between scientific inquiry and commemoration, and often relayed by journalists using local newspapers as outlets for their findings, the dominant nationalistic historiography is broadly disseminated among the wider public. ${ }^{48}$ As such it feeds the very collective memory from which it initially emerges in a mutually reinforcing relationship. Its 
didactic principles about what to remember and what to forget complement perfectly the politics of remembrance behind the initiatives and priorities of the Greek Ministry of Culture in the field of monument restoration in Rhodes, very active in the anastylosis of Ancient Greek, Byzantine, Frankish and, less so, Ottoman monuments, but not so in Jewish memory preservation. ${ }^{49}$ A main authority on Rodeslis, French Geographer Pierre Sintès thus points out that although it is the oldest standing Synagogue in Greece, the Kahal Shalom Synagogue, built in 1577, receives no government funds and depends, for its maintenance, on private patronage or European Union contributions. ${ }^{50}$ Ever since municipal authorities uncovered the Holocaust memorial in 2002, the government's contribution to Jewish remembrance consists in the annual participation of a representative of the southeast Aegean region to the commemoration of the deportation of Rodeslis. Such hands-off policy on behalf of the Government may explain why, in recent years, the Greek national anthem traditionally closing the ceremony is preceded by Israel's national anthem. ${ }^{51}$ Within this context of official disregard, attempts to save the Djuderia from oblivion have mostly been the work, since the 1970s and more so in the 1990s, of descendants of Rodeslis.

\section{Rodesli memoirs as narratives of survival}

Beyond the aforementioned official "Jewish Community of Rhodes," the Rodesli community -in the broader sense of the term "community," implying a social unit of interacting individuals bound by values or purpose- mainly emerges through mutually referential texts authored by individuals across the globe with some family connection to Rhodes. Some of these texts are memoirs penned by Holocaust survivors or by descendants of Rhodian Jews who emigrated before the Second World War in South Africa, the United States, Belgium, Argentina 
and Israel. ${ }^{53}$ Others are well-documented histories written by academics with some Rodesli heritage. Among the latter three have assumed the status of references on the question of Dodecanesian Jews. ${ }^{54}$

The first one is Abraham Galanté's 1935 Histoire des juifs, which he followed up in 1948 with an Appendice à l'histoire des juifs. ${ }^{55}$ Mostly focused on Rhodes, this thoroughly researched inquiry textually constructs the Rodesli community: Its different chapters thus address the historical implementation of Jews in the Aegean islands, their communal and religious institutions, their tax system, the question of emigration in contexts of economic hardship and the community's folklore around popular songs, rituals and even superstitions. Relations with the other communities fall under two chapters, one dedicated to the modalities of the recruitment of Jews in the Ottoman administration and the other to blood libel accusations on the part of Orthodox Christians. Owing to his linguistic versatility, Galanté, who eventually became an influential member of the Republican People's Party after the foundation of the Turkish Republic, was able to use Rabbinic responsa, Ottoman Turkish decrees, Ladino newspapers, Greek sources and $18^{\text {th }}$ and $19^{\text {th }}$ c. European travelogues. As a consequence his work on the Sephardim has become seminal and is regularly quoted by other authors interested in the Rodeslis.

Such is for instance the case of Rabbi Marc D. Angel from New York City with ancestry from Rhodes and his 1978 The Jews of Rhodes. Drawing on Rabbinic responsa and various archives including those of the Alliance Israélite Universelle which operated schools in Rhodes, this book offers an in-depth study of the norms regulating the Rodesli community and the challenges it confronted from the $16^{\text {th }} \mathrm{c}$. to its destruction in $1944 .^{56}$ Also influenced by Galanté's as well as by Angel's work is Esther Fintz-Menascé's1992 Gli Ebrei a Rodi [The Jews 
in Rhodes $].{ }^{57}$ The structure of the book is very similar to that in the work of Galanté and Angel, although relations with local Muslims and Christians are more regularly invoked. With the Greeks these are said to have been decidedly inimical, forcing Rodeslis to barricade themselves in the the Djuderia. This, Fintz-Menascé argues, is what reinforced a feeling of "insularity and isolation," accounting in turn for the cohesiveness and the famed religious observance of the community. ${ }^{58}$ Fintz-Menascé's study is more of a crossover work meant to be as much a historical inquiry as a memorial to the victims of Nazi deportation. Written by a Rodesli born in Rhodes, the book is dedicated to the "memory of the martyrs of Rhodes," it comprises a vast number of written testimonies and homages by Holocaust survivors and their descendants and copies of original sources (pictures, newspaper clips, official dispatches, maps and handwritten letters). More importantly, it acknowledges a number of Holocaust survivors for their help and references some of their works, thereby constituting a link between histories of the Jews of Rhodes and memoirs and biographies of individual Rodeslis.

These latter texts are, for the greater part, openly subjective recollections of a bygone past. Using Paul Ricœur's framework, we could suggest that if Greek narratives partake in the commemoration (commémoration) of a standardized past, Rodesli memoirs are first and foremost "reminiscences" (remémorations), anamnēseis first articulated at the individual level. ${ }^{59}$ The style adopted in these different testimonies reflects the social and educational background of their authors as well as their more or less direct involvement in the narrated events. But they also reproduce common themes, such as vivid descriptions of the religious festivities or the local cuisine, mostly mundane occurrences which all contribute in sustaining personal memories. ${ }^{60}$ Although transcribed recollections, Sylvia Hasson-Berro's 2004 The Story of a Survivor: The Memoirs of Sylvia Hasson-Berro, features among the most personalized accounts within this 
corpus of testimonies. The book does not follow a strict chronological order and instead regularly moves from the after war to the prewar years while the two central chapters are devoted to Sylvia's deportation along with her family. Hailing from a lower-middle to working-class background -her father was an illiterate grocer- Sylvia Hasson-Berro spent the twenty four first years of her existence in Rhodes, working as a ceramic factory worker and then as a grocer's cashier. In the summer of 1944, she was deported to Auschwitz where 45 members of her family were murdered. ${ }^{62}$ Evocations of the other Rhodian communities suggest that relations were cordial with Muslims but tense with Greeks. Eventually, as Jews were being deported, HassonBerro remembers that some "Greeks clapped and jeered, showing their true feelings for their former Jewish neighbors" and eventually seized the property of the departed Jews. ${ }^{63}$ HassonBerro would never return to Rhodes:

As the political situation (...) had changed from Italian to Greek control in 1945, my Italian nationality left me in no man's land, I had no living relatives on Rhodes island and no Jewish community for support. I found myself with nothing to go back to and the past was gone forever - Rhodes island had changed and it was now time for me to change too. ${ }^{64}$

Bouncing off different destinations, Sylvia would eventually settle in Perth, Australia. Informally written and at times factually inaccurate, ${ }^{65}$ The Story of a Suvivor is meant to preserve Hasson-Berro's reminiscences as a specimen of Rhodian Jewish culture as a lived experience rather than a chronologically and factually flawless depiction of the Djuderia under Italian rule.

That same purpose is pursued in Laura Varon's 1999 The Juderia and Rebecca AmatoLevy's 1987 I Remember Rhodes... As she was herself deported, Varon's book is more centered on the destruction of the community, with four of her eight chapters dealing with the 
marginalization and then extermination of the Rodeslis. The tributary dimension of her work emerges in the in memoriam list of family and friends to whom the book is dedicated and the opening chapter, entitled "Joy," a real homage to the liveliness of the Djuderia. Referring to the contrasting Greek and Jewish myths on the origins of Rhodes, Varon writes that "it really didn't matter what one believed. We Jews were a part of Rhodes' history. We had lived on Rhodes at least since the days the Torah was first written." ${ }^{98}$ Rebecca Amato-Levy, who escaped the island in 1939, soon after the promulgation of the Italian anti-Semitic laws, does not refer to the deportation; her entire book is a personalized description of daily life in the Djuderia, the communities' different religious celebrations and popular culture. This commemoration of a once vibrant community is reinforced by the fact that the entire book is published in two languages, English and Ladino, by a nearly exhaustive list of Jewish patronyms used in Rhodes before the Second World War and by a picture with the names of all the Jewish community leaders in the 1930s. ${ }^{69}$ The style in the memoirs of Varon and Amato-Levy is a little more formal which may indicate a more affluent social background than Hasson-Berro but which could be also attributable to the fact that these texts were informed by historical studies, most notably Marc D. Angel's -the Rabbi is in fact acknowledged in Amato-Levy's book ${ }^{70}$ - thus exemplifying what Gwyn Prins referred to as "hermeneutic reinsertion." ${ }^{71}$ Both texts make scant references to intercommunal relations. In her account of the community's final days before deportation, Laura Varon recalls how the mother and daughter of the Turkish family where she was temporarily sheltered begged her not to go to the Air Force headquarters where all Jews had been summoned by the Nazis in July 1944; by contrast she writes that as she and her coreligionists were walked to the boats that would ship them to Athens and thence to the death camps, Greeks "shouted at us as we passed: 'It's good they are taking you from Rhodes. Go away. Do not come back'.,72 
Although published in different countries, at different times, in different languages and according to different writing conventions, all of the above-mentioned texts present a strikingly similar structure with historical overviews succeeded by chronicles of widely spread proverbs, traditions and even superstitions in the community. The same themes are emphasized, such as the liveliness of the Djuderia -also called la Chica Yerushalaim or Little Jerusalem because of its religious radiance in the Near East- the community's attachment to their language, djudezmo/ladino, their religious observance, the importance of their religious celebrations, the cohesiveness of the community in spite of wealth differences or the strongly paternalistic structure of their families. ${ }^{78}$ The same impression of Italian rule is conveyed with a clear distinction between, one the one hand, an initial period up to 1936 when Rodeslis were welltreated by the administration which even worked with the community leaders to open in 1928 a regionally very influential Rabbinical College, and, on the other, a second period starting with the mandate of Governor Cesare Maria de Vecchi (1936-1941) a committed fascist who first implemented the anti-Semitic laws in November $1938 .{ }^{79}$ The same episodes marking the last days of the community are evoked such as the devastation brought to the Djuderia in two consecutive British bombings in 1944 which killed over 20 Rodeslis, the manner in which the island's Sefer Torah was saved by the mufti of Rhodes Şeyh Süleyman Kaslıoğlu and the role of the Turkish consul, Selahettin Ülkümen who saved 47 Rodeslis from deportation by delivering them Turkish passports and who for this was declared one of the Righteous Among the Nations in 1989 by the Yad Vashem Foundation. ${ }^{80}$ Equally importantly, all of these texts, independently of their specific genre, assert as their primordial purpose a "devoir de mémoire." ${ }^{" 1}$ These shared motifs function as recognizable pointers and signs, indeed as language, "a shared medium within which alone individuals can remember or articulate themselves." 82 This "language" in turn, 
forms the basis over which an intertextual community emerges, transforming the Djuderia into a place, "[a]n island within an island, within an island (...)," ${ }^{83}$ disconnected from its immediate insular context, but reconnected to regional and global places of exile.

Indeed these recollections draw the contours of a broader geography, what Sintès has called the "network-space" of the Rodesli diaspora in the United States, South Africa, Belgium, Argentina or Israel.$^{85}$ Feeding a common narrative of survival they are increasingly relayed by the commemorative initiatives of the Central Board of Jewish Communities in Greece. In an instantiation of memory tourism, descendants of Rodeslis regularly meet in the Old Town for different festive occasions and for Holocaust Remembrance Day which in Rhodes is held on 23 July, the day of the deportation of Rhodian Jews instead of the customary 27 January, anniversary of the liberation of Auschwitz. ${ }^{86}$ Hence narratives, monuments, travels and rituals work together to convert Rhodes into what Pierre Nora called a "lieu de mémoire," a site of memory, capturing an intermediary situation between real, but disappearing experienced environments of memory, and history ${ }^{87}$ Allusions to Greeks are scarce and Greece is never a reference in the self-understanding of the descendants of Rodeslis. Although this is primarily due to the fact that Rodeslis have never been Greek citizens -the community no longer existed when Rhodes was integrated to Greece for the first time in 1947- it is compounded by the main purpose of the lieu de mémoire in question -namely to maintain alive the memory of the Jewish community of Rhodes.

\section{Parallel communal stories, taboos and the Mediterranean's elusive cosmopolitanism}

Evolving on different planes, these two differently configured "lieux de mémoire," Greek and Rodesli, are a transgenerational memorial capital reinforcing a sense of mutually exclusive 
communal belonging. Their different nature -Greek history as opposed to Rodesli memory- is indicative of the power relations in which they emerged ${ }^{89}$ : the former is a commemoration of a vindication while the latter, to paraphrase Zemon Davis and Starn, is "a substitute, surrogate, or consolation for something that is missing," it is, in other words, "an index of loss." 90 The difficulty of putting them in dialogue with one another preempts the emergence of a social space which would authorise a history of the island taking into account its erstwhile cultural diversity, one aware of "the dangers that inhere univocal narratives." 91 Of course one should be wary not to overemphasize some procrustean coherence and cohesion of "Greek" as opposed to "Rodesli" evocations of the past. As we have seen there are, in these texts, fissures along social class lines and a gradient of proximity to the narrated events. ${ }^{92}$ On a more empirical side, a reading against the grain of local Italian archives will reveal traces of -licit and illicit- intercommunal sociability. ${ }^{93}$ The relevant question for our purposes is not whether such relations existed or not but rather why they are nowadays not or little investigated.

Three main reasons may be advanced to address this problem of soliloquy. The first and more obvious one, constituting the core of the analysis in this paper, has to do with the different intentionality of these corpuses: while Greek texts are anti-colonial, nationalistic narratives intended to bolster communal identity in the face of external threat, Rodesli narratives are testimonies to the destruction of a community. This differing intentionality may be however observed in Greek and Jewish narratives beyond the Rhodian case, which leads us to a second, more structural reason behind the question of soliloquy. Indeed the historiography of the region has often reproduced a sort of essentialized antithesis between Greek and Jewish identities, taking as a given their mutual exclusiveness; this is visible for instance in numerous studies devoted entirely to the diachronic relations between "Greeks" and "Jews." ${ }^{94}$ From a state 
perspective such binary division might have been operative as religion played a crucial factor in the construction of national identities in the post-Ottoman Eastern Mediterranean. ${ }^{95}$ But this is simply untenable when one is interested in the everyday social relations and practices which challenged strict legal and religious boundaries.

From a more material perspective, a third and final reason behind this phenomenon of soliloquy in Greek and Jewish narratives is most likely connected to the question of Jewish property seizure. ${ }^{98}$ Indeed by and large, Jewish property seizure in Rhodes falls within the realm of what Zerrin Özlem Biner, following Michael Taussig, calls "public secrecy," namely "a limit case of what not to know but also of that which is generally known but cannot be spoken." 99 While the massive expropriation of lands belonging to Greeks in Rhodes, Kos and Leros by the Italians has been and is still rightfully documented, the fate of Jewish property in the island has only been systematically examined by the Jewish Community of Rhodes and the Rhodes Jewish Museum. ${ }^{100}$ This indexing of former Jewish properties cannot, it appears, constitute a legal basis for reparation. Rhodes and Kos fell outside of the purview of the official Organization for the

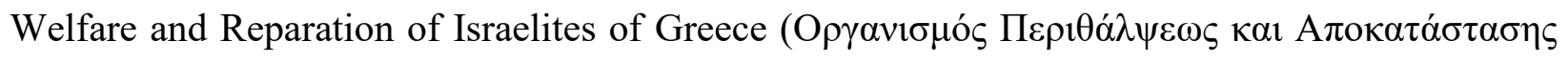
I $\left.\sigma \rho \alpha \eta \lambda \tau \tau \dot{v} v \mathrm{E} \lambda \lambda \lambda_{\alpha} \delta \mathrm{s}\right)$, created with the aim, among other things, to restore illegally occupied Jewish properties. Indeed, as mentioned before, the few Rodeslis having survived the Holocaust were not Greek citizens before or even after the Second World War; and this, despite the fact that Yad Vashem classifies them as Greek Jews. ${ }^{101}$ But beyond legal concerns, the enduring silence over the topic of property seizure poses an epistemological challenge to scholars interested in intercommunal relations in the modern era. And in this, Rhodes is an emblematic, rather than unique, case in the Eastern Mediterranean. 
Indeed the fate of minority property has been perhaps the major impediment in the study of intercommunal relations in the late $19^{\text {th }}$ and early $20^{\text {th }}$ Eastern Mediterranean. As Maryline Crivello points out, this has led to the formulation of exclusive national narratives reinforced by insecurities related to the recently established -and therefore still contested- homogeneity of Mediterranean nations and the legitimacy of their states. ${ }^{103}$ In other words, any explicit reference to the illegitimate ways in which property belonging to other ethnic minorities is perceived by officially-sanctioned histories as a threat to the legitimacy of the nation-state itself. But "[c]ontrary to the ordered memory of the archive," as Iain Chambers writes, "to the filed away names, events, and explanations, there is the persistent murmur of a world whose insistent 'noise' betrays the order that seeks to regulate, and in the end, remove it." ${ }^{104}$ More and more researchers have indeed chosen to pay attention to this "murmur," override the various forms of cultural or sometimes legal censorship to explore the dissonance, throughout the region, between nationalist narratives and unofficial or marginal memories. Recent work on the confiscation of Armenian property by the Young Turks and the Turkish Republic or that of Muslim and later Jewish property in Salonica/Thessaloniki by the Greek state highlight the often denied destructive nature of nation-state formation around the Mediterranean following the gradual collapse of the Ottoman Empire. ${ }^{105}$ Rebecca Bryant's research on post-intercommunal conflict Cyprus also reveals the often very material foundations of what she calls the "partition of memory" between Greek and Turkish Cypriots. Property seized, Bryant notes, is never fully appropriated by its new owners; it is a site without a past or rather with a hidden past that resists any attempt at obfuscation. And so, "these remains of history become history's remainders, pieces in a past that do not fit, and hence reminders of a past that is unfinished and so capable of molding the present in new and unexpected ways." 107 Indeed, by directly confronting the 
selective amnesias of official histories, such work highlights the political difficulty in writing about intercommunal relations in the modern period. Whether scholarly or meant for a broader readership, these studies also underscore the corrupting effects of denial on tolerance to diversity, supposed to be the bedrock of contemporary democratic polities.

Yet this paper suggests that the violence that put an end to erstwhile multicultural settings -and its consolidation through property transfers- is not the only reason behind "partitions of memory" and the production of soliloquous narratives in the Eastern Mediterranean. Indeed a careful reading of our sources seems to suggest that interactions across communal lines were tenuous and formal long before the trauma of separation. To return to our Rodesli testimonies, there seems to be a genuine element of surprise at the fact that certain Greeks applauded the 1944 deportations or, on the contrary, at the readiness of Muslim families to provide shelter to persecuted Jews. Indeed, if the deportations revealed anything about intercommunal relations in Rhodes, it is that the island's different communities seemed to have known little about one another. To the extent that Rhodes may be considered as an emblematic case in the Eastern Mediterranean, this observation does call for a corrective to that quintessentially Mediterranean trope, "cosmopolitanism," which is often considered to have characterized pre-national Eastern Mediterranean regions. Of course this notion of a pre-national cosmopolitanism, coterminous with a post-Braudelian understanding of the Mediterranean, has been undergoing sustained critique for the past thirty years. ${ }^{109}$ Mostly research has been concerned with an uncritical usage of the notion of cosmopolitanism, impervious to the power relations that enabled an economically and politically privileged elite to be "cosmopolitan," that is, to entertain a semicolonial, cross-cultural sociability at the expense of a local, poorer, and as a consequence culturally much less fluid population. ${ }^{110}$ What our sources do suggest, is how speculative it is to 
assign any a priori quality to pre-national cross-cultural interactions. Establishing that different religious groups coexisted for a long period of time in a specific location is not sufficient to allow us to infer anything about the nature of their mutual relations. And so we find ourselves facing the central question running through this paper: how do we use soliloquous sources to imagine past societies defined by their cultural diversity without falling in the trap of invoking "multiculturalism" or "cosmopolitanism"? ${ }^{111}$ Interestingly, in seeking to grasp an intercommunal past without reverting to idealized references to cosmopolitanism, many students of the Eastern Mediterranean invoke the "ghosts" of past-deported or annihilated- communities in any given setting, from mainland Greece to Anatolia, through Cyprus and Israel and Palestine. This figure of the ghost, which literally pervades the literature on the region, is meant to evoke the violence of the destruction of a given community and the lingering signs of its erstwhile existence in the built environment, oral testimonies and traditions and in documents. The ghost becomes both a metaphor for, and the witness of, vanished culturally diverse societies. ${ }^{112}$ Overall however, the "ghost" in this literature remains a rhetorical figure rather than a proper analytical concept.

A major reference in helping us shoring up the analytical purchase of the figure of the ghost is Jacques Derrida's Specters of Marx. In this series of lectures aimed to devise a hauntology as an approach and a method able to address what Derrida considers to be some of the innate flaws of ontology and phenomenology, the author writes that all hegemonic discourses -historical and otherwise- necessitate in their formulation the concealment of signs that contradict their unifying principle. ${ }^{118}$ But because these repressed traces can never be suppressed, they permanently haunt and threaten univocal narratives. ${ }^{119}$ To break out of this logic leading to ever more coarse devices used against the stubborn presence of ghosts, it is necessary, according to Derrida, to learn to live with them, in their companionship, how to "talk with him, with her, 
how to let them speak or how to give them back speech," 120 to allow them to "work" and make us work. ${ }^{121}$ For the purposes of this paper, this means acknowledging that the sheer existence of apparently incommensurable sources dealing with the same events force us to forsake, in our own accounts, any unifying principle -such as characterizes "collective memories"- and accept to "gather under a single roof the apparently disordered plurivocity"122 of different recollections. As a reading and writing technique this would require a bold departure from the time-honoured "synthesis": the goal would thus no longer be to use one discourse as a corrective to the other with a view to finding a presumably more plausible version of the past. Indeed proceeding in such a way would not resolve the basic problem of competitive memory inherent in the very production of the sources; the brittle consensual memory established in this manner would not resist long before temptations to restore a "hierarchy of suffering" that seems to be congenital in much of the historiography of the Eastern Mediterranean. Instead, the various sources at hand should be treated on equal -and "disjointed"- terms, an approach respectful of their difference.

Although not informed by hauntology, this disjointed treatment of sources has already shown its heuristic potential in contexts both Mediterranean and extra-Mediterranean. Hence in his analysis of Ottoman Cyprus in the nineteenth century, Marc Aymes proposes a writing method which he terms "polygraphy" -as opposed to the familiar monography- which consists in elaborating on the differences between his sources (Ottoman reports, European narratives). This enables him to convincingly revise, from the viewpoint of what appears to be a small administrative backwater -Cyprus- some central metanarratives which have long informed research on the Ottoman Empire (Westernization, modernization, nationalization, reforms, etc.) Likewise, through a parallel reading of both European and Indonesian sources, Romain Bertrand comes to the surprising, but paradigm-changing conclusion that the so-called "colonial 
encounter" "never took place" in Early Modern Indonesia, at least from the point of view of the

locals. ${ }^{123}$ Building on such insightful studies using, at the same time, hauntology, which appears particularly adapted to the violence with which culturally diverse Mediterranean societies were brought to an end, allows for the conceptualization of a form of history-writing determined to give voice to all the sources, despite their soliloquous nature and the asymmetrical relations of power that presided over their production. Only this would enable a progression from a "duty of memory" (devoir de mémoire) externally imposed and therefore condemned to forever remain foreign to a just memory (juste mémoire).

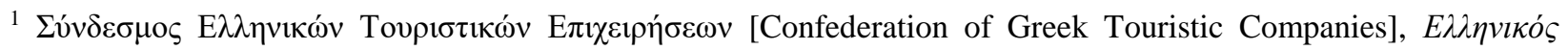

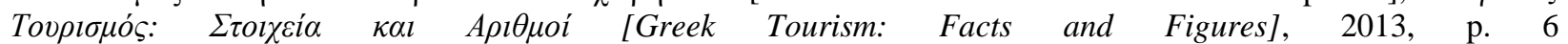
http://sete.gr/fileuploads/tourism_Facts_Figures/FACTS\%20\%20FIGURES\%202013.pdf. Accessed August 27, 2014. And http://www.rhodes-airport.org/airlines/. Accessed August 27, 2014.

${ }^{2}$ For the history of Italian architecture in the Dodecanese see McGuire, "Arcadian Histories," and Antoniades, "Italian Architecture."

${ }^{3}$ McGuire, "Remnants of Empire," 104.

${ }^{5}$ The term means "Rhodian" in Turkish and has been historically employed to designate the Jews from Rhodes.

${ }^{6}$ Toliou and Clementi, Gli ultimi ebrei di Rodi.

${ }^{7}$ This is not so for the Early Modern Period, both Ottoman and pre-Ottoman where such relations are either evoked at some length or indeed at the center of these studies. See for instance Vatin, L'Ordre de Saint-Jean de Jérusalem

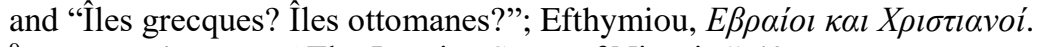

${ }^{9}$ Hatay and Bryant, "The Jasmine Scent of Nicosia," 426.

${ }^{10}$ While Holocaust memory has played a considerable role in the articulation of a Western European sense of self, this has not always been the case in Eastern and Southeastern Europe where the Holocaust has often been relegated to the status of a "weak memory" partly overshadowed as it was by narratives of resilience, resistance and redemption against foreign occupiers from the Ottoman times to the present. The same applies to post-colonial settings. On the conflict between Holocaust and post-colonial memories see Rothberg, Multidirectional Memory, 6, 8, 12 and 23; and Traverso, Le passé mode d'emploi, 55. For the particularly dense conflict of memories in the Eastern Mediterranean, see Crivello, "Les arts de la mémoire," 24-25.

${ }^{12}$ Marrus, The Unwanted, 40-52.
} 
${ }^{13}$ The expression "refrigerated" in Crouzet, Le conflit de Chypre, 47 and Holland, Britain and the Revolt in Cyprus, 8. For an elaboration on how nation-state (and by extension colonial) borders severed different Judeo-Spanish communities from the organic links they had developed with one another under the Ottomans, see Benbassa and Rodrigue, Sephardi Jewry, xxii-xxiv.

${ }^{14}$ Kaurinkoski, "The Muslim Communities," 54.

${ }^{17}$ Gross, "The Situation of the Inhabitants of Rhodes and Kos," 4.

${ }^{18}$ Kaurinkoski, "The Muslim Communities," 57 and 64.

${ }^{19}$ Nasuhoğlu, Rodos; Orakçı, Rodos Müslümanları. For a scholarly work on the Muslims of Rhodes before the Italian occupation see Örenç, Yakındönem tarihimizde Rodos ve Oniki Ada.

${ }^{20}$ Sintès, "Retrouver Rhodes," 39.

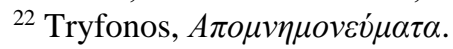

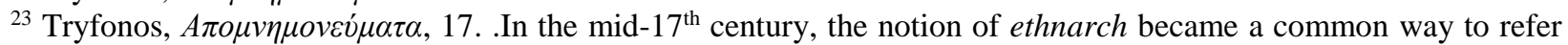
to the special position played by Orthodox prelates under Ottoman rule, invested as they were with wide civil and political prerogatives.

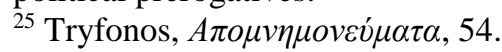

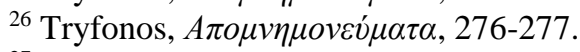

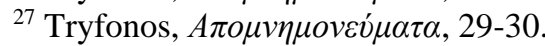

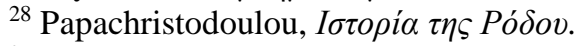

${ }^{29}$ Later on Papachristodoulou would be the first one to organize and index the Italian official archives left in Rhodes.

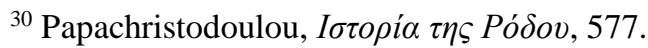

31 In 1924, Bishop Apostolos Tryfonos engaged into negotiations with Italian authorities regarding a highly unpopular scheme to make the Church of the Dodecanese autocephalous, namely independent from the Patriarchal See of Constantinople, with himself at its head; fueled by attacks in the Dodecanesian diasporic press in Athens, Greece, Alexandria, Egypt, and in New York, rumours began circulating that this was the initial step within a larger design to Catholicize the Archipelago's Greek-Orthodox Christians, itself a stepping stone towards the Italianization of the islands. This created a durable rift within among the Greek-Orthodox Dodecanesian notables, intellectuals and clergy and would lead, when the British shortly administered the Dodecanese following the end of the Second World War, to the bishop's forced resignation in June 1946. On this issue see Marongiu-Buonaiuti, La politica religiosa del fasismo. To this day, the Dodecanesian Church is subordinate to the Partiarch of Constantinople while the large majority of the other Orthodox Churches in Greece are subordinate to the Archbishop of Athens and All Greece.

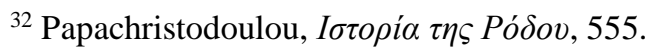

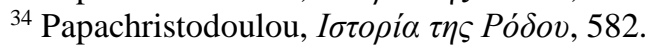

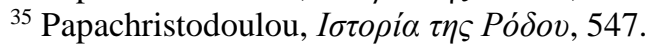

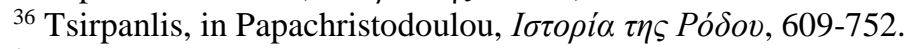

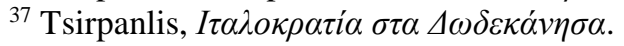

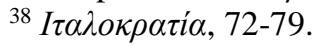

${ }^{39}$ Tourkokratia for the entire Ottoman period, Enetokratia in reference to the Venetian domination of different parts of what is today Greece between 1204 and 1797, and Anglokratia in reference to the British occupation of the Ionian Islands (1815-1864) and Cyprus (1878-1960).

${ }^{41}$ Hamilakis The Nation and Its Ruins, 27, Liakos, "The Construction of National Time" and Avdela, "The Teaching of History in Greece," 245.

${ }^{42}$ Doumanis and Pappas, "Grand History in Small Places."

${ }^{43}$ Doumanis and Pappas, "Grand History," 113.

${ }^{44}$ Avdela, "The Teaching of History," 243.

${ }^{45}$ For the citation see Avdela, "The Teaching of History," 242.

${ }^{47}$ Sintès, "Retrouver Rhodes," 43.

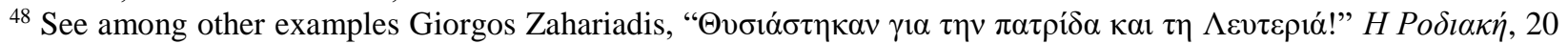
September 2014. For alternative methodologies mobilized to upset the homogenizing pretensions of nationalistic narratives based on oral history see Doumanis, Myth and Memory in the Mediterranean.

${ }^{49}$ Sintès, "Retrouver Rhodes," 42. For a general exploration of the embodiment and materialization of "nation and nationhood" in Greece in "ancient things, places and sites," see Hamilakis, The Nation and Its Ruins, 10-16. Only in July 2014 did the state, in the form of the department of culture of the South Aegean Region and the General State Archives of the Prefecture of the Dodecanese, contribute to a "Commemorative International Symposium on the 
Holocaust in the Aegean," co-sponsored by the Jewish Community of Rhodes, the University of Limerick and the University of the Aegean. See https://forum.aegean.gr/download/file.php?id=15166. Accessed July 7, 2017.

${ }^{50}$ Sintès, "Retrouver Rhodes," 42-43.

${ }^{51}$ Sintès, "Retrouver Rhodes," 43.

${ }^{53}$ Guidi, "Patterns of Jewish Mobility," and Hirschon, "Jews from Rhodes in Central and Southern Africa."

${ }^{54}$ Excluded from this analysis is the growing number of scientific inquiries penned by non-Dodecanesians which address the question of the Rodeslis, such as Liliana Picciotto's Libro della memoria.

${ }^{55}$ Galanté, Histoire des juifs de Rhodes and Appendice..

${ }^{56}$ Angel, The Jews of Rhodes.

${ }^{57}$ Fintz-Menascé, Gli Ebrei a Rodi.

${ }^{58}$ Fintz-Menascé, Gli Ebrei a Rodi, 140.

${ }^{59}$ Ricœur, La mémoire, 32. For elaborations on the distinction (Aristotelian in origin) between, on the one hand, memory $-m n \bar{e} m \bar{e}-$ as the almost pathological occurrence of the past to the mind and anamnesis as the effort to reminisce the past, see Ricœur, La mémoire, 4 and 32.

${ }^{60}$ For the mundane as support for personal reminiscences, see Ricœur, La mémoire, 44. See also Rebecca Bryant, The Past in Pieces, 30.

${ }^{62}$ The Story of a Survivor, 8-9, 45.

${ }^{63}$ The Story of a Survivor, 51-52.

${ }^{64}$ The Story of a Survivor, 51-52.

${ }^{65}$ In some of the memoirs under review here there is an occasional confusion regarding the dates of specific events involving the entire island. This is probably due to the young age of the authors at the time of said events and perhaps also to the nature of these texts which focus on individual lived experiences rather than geopolitical developments. It may also be, as Gwyn Prins stresses in his reading of Primo Levi's The Drowned and the Saved, the result of the trauma of the death camps, Prins, "Oral History," 132.

${ }^{68}$ Varon, The Juderia, 2.

${ }^{69}$ Amato-Levy, I Remember Rhodes, 3 and 149.

${ }^{70}$ Amato-Levy, I Remember Rhodes, xii.

${ }^{71}$ Prins, "Oral History," 132.

72 Varon, The Juderia, 37-39. The Rodesli literature also includes a number of titles of a less easily identifiable genre, particularly from descendants of Rodesli Holocaust survivors whose narratives are informed both by family stories and their own readings. See for example Benatar, Rhodes and the Holocaust, Hazàn, Un dia màs de vida, Franco, The Jewish Martyrs of Rhodes and Cos, Levy, Jewish Rhodes, Alhadeff, The Sun at Midday.

${ }_{78}$ Varon, The Juderia, 3 and 19; Hasson-Berro, The Story of a Survivor, 72-89; Angel, The Jews of Rhodes, 112; Levy, Jewish Rhodes, 29-31; as mentioned earlier, Amato-Levy's I Remember Rhodes is entirely devoted to such recollections. See also Sintès, "(Re)construire la Djuderia de Rhodes," 21.

${ }^{79}$ Varon, The Juderia, 15-17; Amato-Levy, I Remember Rhodes, 30; Angel, The Jews of Rhodes, 39, 84-85 and 149151; Hazan, Un dia màs de vida, 36-37; Levy, Jewish Rhodes, 37-38.

${ }^{80}$ Varon, The Juderia, 28-32; Benatar, Rhodes and the Holocaust, 22-23 and 31; Hasson-Berro, The Story of a Survivor, 52-53; Angel, The Jews of Rhodes, 151-152; Hazan, Un dia màs de vida, 50.

${ }^{81}$ Amato-Levy, I Remember Rhodes, unnumbered opening page; Hasson-Berro, The Story of a Survivor, 7; Hazan, Un dia màs de vida, opening page.

${ }^{82}$ Rothberg, Multidirectional Memory, 15.

${ }^{83}$ Alhadeff, The Sun at Midday, 70, referring to the fact that the Djuderia was a neighborhood within the walled medieval capital of the island of Rhodes.

${ }^{85}$ For the expression "network-space" see Sintès, "Mi akrodo de Rhodes," 111. The social practices and rituals shaping this network-space are more thoroughly examined in his "(Re)construire la Djuderia de Rhodes," 21-26. See also his "Retrouver Rhodes," 37.

${ }^{86}$ Sintès, "Retrouver Rhodes," 40-41 and 43. Sintès also uses the expression "genealogical tourism" (p. 41) to refer to the fact that many of these tourists are descendants of Rodeslis anxious to visit the place from where their family originates.

${ }^{87}$ Nora, "Between Memory and History."

${ }^{89}$ Baussant, "Penser les mémoires," 390.

${ }^{90}$ Zemon Davis and Starn, "Introduction," 3-4.

${ }^{91}$ Stroebel, "Distancing Disaster," 256. 
${ }^{92}$ For an elaboration on the socioeconomic divide and conflicts within different communities of Ottoman Jewry, Rodrigue, "Introduction."

${ }^{93}$ Guidi, "Defining Inter-Communality" and Rappas, "Insularity and Ethnicity."

${ }^{94}$ See for example, from a more theological perspective, Constantelos, "Greek Orthodox-Jewish Relations" and Ankori, "Greek Orthodox-Jewish Relations in Historical Perspective-The Jewish View." This is extremely present, to the point of caricature, in Shachar, The Lost World. See also Pierron, Juifs et chrétiens. More nuanced is the approach of Mark Mazower whose Salonica, City of Ghosts has an entire chapter entitled "Greeks and Jews," 402420.

${ }^{95}$ See Mavrogordatos, "Orthodoxy and Nationalism in the Greek Case," who reminds us that during the early moments of the Greek War of Independence, religion was "the only fixed line of demarcation among the warring sides" (p. 128, italics in the text). The same argument in Hirschon, "Dismantling the Millet."

${ }^{98}$ Sintès, "Mi akrodo de Rhodes," 119-121.

${ }^{99}$ Biner, "Acts of Defacement," 74-75.

${ }^{100}$ A close examination of the Italian cadastral survey allowed the "Rhodes Jewish Museum" founded by Aron Hasson to draw very precise maps of former Jewish properties and businesses in the Old Town, see http://www.rhodesjewishmuseum.org/juderia. Accessed June 17, 2017. On the genealogy of the Rhodes Jewish Museum see Sintès, "La synagogue au musée," 680-682.

${ }^{101}$ Fleming, Greece: A Jewish History, 6.

${ }^{103}$ Crivello, "Les arts de la mémoire," 14.

${ }^{104}$ Chambers, Mediterranean Crossings, 56-57.

105 Üngör, The Making of Modern Turkey; Biner, "Acts of Defacement," 73; Apostolou, “"The Exception of Salonica," 180.

${ }^{107}$ Bryant, The Past in Pieces, 149.

109 "Herzfeld, "The Horns of the Mediterraneanist," and "Practical Mediterraneanism."

${ }^{110}$ A recent and very systematic critique of cosmopolitanism can be found in Hanley, "Grieving Cosmopolitanism."

${ }^{111}$ For a stimulating recoding of the concept of "cosmopolitanism" as an attribute "ascribed rather than achieved," see Brink-Danan, Jewish Life in $21^{\text {st }}$ Century Turkey, 29.

112 Mazower, Salonica; Kaplan, Balkan Ghosts; Biner, "Acts of Defacement"; Clark, Twice a Stranger, 21-41; Roberts, Contested Land, Contested Memory; Marchand and Perrier, Turkey and the Armenian Ghost. See also in the case of Rhodes, Sintès, "Retrouver Rhodes," 39; Shachar The Lost Worlds of Rhodes, 8.

${ }^{118}$ Derrida, Specters of Marx, 63 and 202.

${ }_{119}$ Derrida, Specters of Marx, 46. For an example in Cyprus, see Bryant, The Past in Pieces, 57.

${ }^{120}$ Derrida, Specters of Marx, 221.

${ }^{121}$ For a very engaging use of Derrida's hauntology in the realm of film studies, see Arınç, "Postcolonial Ghosts."

122 Derrida, Specters of Marx, 25.

${ }^{123}$ Aymes, Provincial History and Bertrand, L'histoire à parts égales.

\section{Bibliography}

Alhadeff, Gini. The Sun at Midday: Tales of a Mediterranean Family. New York: Pantheon Books, 1997.

Amato-Levy, Rebecca. I Remember Rhodes... New York: Sepher-Hermon Press, 1987.

Angel, Marc D. The Jews of Rhodes: The History of a Sephardic Community. New York: SepherHermon Press and the Union of Sephardic Congregations, 1978. Reprint, New York: SepherHermon Press and the Union of Sephardic Congregations, 1998. Page references are to the 1998 edition.

Ankori, Zvi. "Greek Orthodox-Jewish Relations in Historical Perspective: The Jewish View." The Greek Orthodox Theological Review 22 (1977): 17-57. 
Antoniades, Anthony C. "Italian Architecture in the Dodecanese: A Preliminary Assessment." Journal of Architectural Education 38, no. 1 (1984): 18-25. doi:10.1080/10464883.1984.10758348.

Apostolou, Andrew. "'The Exception of Salonica': Bystanders and Collaborators in Northern Greece." Holocaust and Genocide Studies 14, no. 2 (2000): 165-190. doi: 10.1093/hgs/14.2.165.

Arınç, Cihat, "Postcolonial Ghosts in New Turkish Cinema: A Deconstructive Politics of Memory in Derviş Zaim's ‘The Cyprus Trilogy’.” PhD diss., Goldsmiths College, University of London, 2015.

Avdela, Efi. "The Teaching of History in Greece." Journal of Modern Greek Studies 18, no. 2 (2000): 239-253. doi: 10.1353/mgs.2000.0025.

Aymes, Marc. A Provincial History of the Ottoman Empire: Cyprus and the Eastern Mediterranean in the Nineteenth Century. London: Routledge, 2013.

Baussant, Michèle. "Penser les mémoires [Thinking Memories]." Ethnologie française 37, no. 3 (2007): 389-394. doi: 10.3917/ethn.073.0389

Benatar, Isaac. Rhodes and the Holocaust: The Story of the Jewish Community from the Mediterranean Island of Rhodes. Bloomington: iUniverse, 2010.

Benbassa, Esther and Aron Rodrigue. Sephardi Jewry: A History of the Judeo-Spanish Community, $14^{\text {th }}-20^{\text {th }}$ Centuries. Berkeley: University of California Press, 1993. Reprint, Berkeley: University of California Press, 2000. Page references are to the 2000 edition.

Bertrand, Romain. L'histoire à part égales. Récits d'une rencontre Orient-Occident. Paris: Seuil, 2011.

Biner, Zerrin Özlem. "Acts of Defacement, Memory of Loss: Ghostly Effects of the "Armenian Crisis' in Mardin, Southeastern Turkey." History and Memory 22, no. 2 (2010): 68-94. doi: 10.2979/his.2010.22.2.68.

Brink-Danan, Marcy. Jewish Life in $21^{\text {st }}$ Century Turkey: The Other Side of Tolerance. Bloomington: Indiana University Press, 2011.

Bryant, Rebecca. The Past in Pieces: Belonging in the New Cyprus. Philadelphia: University of Pennsylvania Press, 2010. 
Chambers, Iain. Mediterranean Crossings: The Politics of an Interrupted Modernity. Durham: Duke University Press, 2008.

Clark, Bruce. Twice a Stranger: How Mass Expulsion Forged Modern Greece and Turkey. London: Granta Books, 2006.

Clementi, Marco and Eirini Toliou. Gli ultimi ebrei di Rodi: leggi razziali e deportazioni nel Dodecaneso italiano (1938-1948). Roma: DeriveApprodi, 2015.

Constantelos, Demetrios J. "Greek Orthodox-Jewish Relations in Historical Perspective." The Greek Orthodox Theological Review 22 (1977): 6-16.

Crivello, Maryline. "Les arts de la mémoire en Méditerranée [The arts of memory in the Mediterranean]." In Les échelles de la mémoire en Méditerranée (XIXe-XXe siècles) [The scales of memory in the Mediterranean $\left(19^{\text {th }}-20^{\text {th }} \mathrm{c}\right.$.)], edited by Maryline Crivello, $13-31$. Arles: Actes Sud, 2010.

Crouzet, François. Le conflit de Chypre 1946-1959 vol. 1 [The Cyprus conflict, 1946-1959, vol.1]. Brussels: Emile Bruylant, 1973.

Derrida, Jacques. Specters of Marx: The State of the Debt, the Work of Mourning and the New International. Translated by Peggy Kamuf. New York: Routledge, 1994.

Doumanis, Nicholas. Myth and Memory in the Mediterranean: Remembering Fascism's Empire. New York: St. Martin's Press, 1997.

Doumanis, Nicholas and Nicholas Pappas. "Grand History in Small Places: Social Protest on Castellorizo (1934).” Journal of Modern Greek Studies 15, no. 1 (1997): 103-123. doi: 10.1353/mgs.1997.0009.

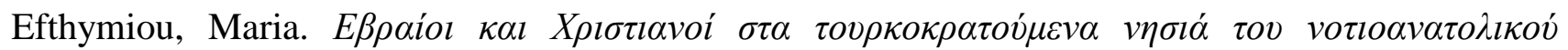

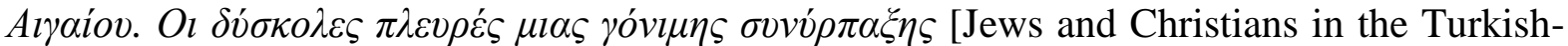
Administered Islands of the Southeast Aegean: The Difficult Dimensions of a Fruitful Coexistence]. Athens: Trochalia, 1992.

Fintz-Menascé, Esther. Gli Ebrei a Rodi: Storia di an'antica comunità annientata dai nazisti [The Jews in Rhodes: History of an ancient community annihilated by the Nazis]. Milan: Guerini e Associati, 1992. Reprint, Milan: Guerini e Associati, 2000. Page references are to the 2000 edition. 
Franco, Hizkia M. The Jewish Martyrs of Rhodes and Cos. Translated by Joseph Franco. Zimbabwe: HarperCollins, 1994.

Galanté, Abraham. Histoire des juifs de Rhodes, Chio, Cos, etc. [History of the Jews of Rhodes, Chio, Kos, etc.]. Istanbul: Société Anonyme de Papeterie et d'Imprimerie (Fratelli Haim), 1935.

Galanté, Abraham. Appendice à l'Histoire des juifs de Rhodes, Chio, Cos, etc. et fin tragique des communautés juives de Rhodes et de Cos, euvre du brigandage hitlérien [Appendix to the History of the Jews of Rhodes, Chio, Kos, etc. and the tragic end of the Jewish communities of Rhodes and Kos, as a result of Hitlerite banditry]. Istanbul: Kâğit ve Basim İşleri, 1948.

Gross, Andreas. The Situation of the Inhabitants of Rhodes and Kos with a Turkish Cultural Background. Report, Committee on Legal Affairs and Human Rights, Doc. 12526, Parliamentary Assembly, Council of Europe, 23 February 2011.

Guidi, Andreas. "Defining Inter-communality between Documents, Tradition and Collective Memory: Jewish and Non-Jewish Capital and Labor in Early Twentieth Century Rhodes." Southeast European and Black Sea Studies 17, no. 2 (2017): 165-180. doi: 10.1080/14683857.2017.1324266.

Guidi, Andreas. "Patterns of Jewish Mobility Between Rhodes and Buenos Aires (1905-1948)." Südosteuropäische Hefte 4, no. 2 (2015): 13-24.

Fleming, Katie. Greece: A Jewish History. Princeton: Princeton University Press, 2009.

Hamilakis, Yannis. The Nation and Its Ruins: Antiquity, Archaeology and National Imagination in Greece. Oxford: Oxford University Press, 2007.

Hanley, Will. "Grieving Cosmopolitanism in Middle East Studies." History Compass 6, no. 5 (2008): 1346-1367. doi: 10.1111/j.1478-0542.2008.00545.x.

Hasson-Bero, Sylvia, The Story of a Survivor: The Memoirs of Sylvia Hasson-Berro. Selfpublication by Lucille Berro-Stein and Vivienne Berro-Gtitzman, 2004.

Hatay, Mete and Rebecca Bryant. "The Jasmine Scent of Nicosia: Of Returns, Revolutions, and the Longing for Forbidden Pasts.” Journal of Modern Greek Studies 26, no. 2 (2008): 423-449. doi: 10.1353/mgs.0.0032. 
Hazàn, Martin. Un dia màs de vida. Rodas-Auschwitz-Buenos Aires. La odisea de David Galante [One more day of life. Rhodes-Auschwitz-Buenos Aires. The Odyssey of David Galante]. Buenos Aires: Lumiere, 2007.

Herzfeld, Michael, "Practical Mediterraneanism: Excuses for Everything, From Epistemology to Eating." In Rethinking the Mediterranean, edited by William V. Harris, 45-63. Oxford: Oxford University Press, 2005.

Herzfeld, Michael, "The Horns of the Mediterraneanist Dilemma." American Ethnologist 11, no. 3 (1984): 439-454. doi: 10.1525/ae.1984.11.3.02a00020.

Hirschon, Renée. "Dismantling the Millet: Religion and National Identity in Contemporary Greece." In Nationalism in the Troubled Triangle: Cyprus, Greece and Turkey, edited by Ayhan Aktar, Niyazi Kızılyürek and Umut Özkırımlı, 61-75. Basingstoke: Palgrave Macmillan, 2010.

Hirschon, Renée. "Jews from Rhodes in Central and Southern Africa." In Encyclopedia of Diasporas: Immigrant and Refugee Cultures Around the World. Volume 2: Communities, edited by Melvin Ember, Carol R. Ember, and Ian Skoggard, 925-934. New York: Springer, 2005.

Holland, Robert. Britain and the Revolt in Cyprus, 1954-1959. Oxford: Clarendon Press, 1998.

Kaplan, Robert D. Balkan Ghosts: A Journey Through History. New York: Vintage Departure, 1994. Kaurinkoski, Kira. "The Muslim Communities in Kos and Rhodes: Reflections on Social Organization and Collective Identities in Contemporary Greece." In Balkan Encounters: Old and New Identities in South-Eastern Europe, edited by Jouko Lindstedt and Maz Wahlström, 47-78. Helsinki: Slavica Helsingiensia 41, 2012.

Levy, Isaac Jack. Jewish Rhodes: A Lost Culture. Berkeley: Judah L. Magnes Museum, 1989.

Liakos, Antonis. "The Construction of National Time: The Making of the Modern Greek Historical Imagination." Mediterranean Historical Review 16, no. 1 (2001): 27-42. doi: $10.1080 / 714004571$.

Marchand, Laure and Guillaume Perrier. Turkey and the Armenian Ghost: On the Trail of Genocide. Translated by Debbie Blythe. Montréal: McGill-Queen's University Press, 2015.

Marongiu-Buonaiuti, Cesare. La politica religiosa del fasismo nel Dodecaneso. Naples: Giannini, 1979. 
Marrus, Michael R. The Unwanted: European Refugees in the Twentieth Century. Oxford: Oxford University Press, 1985.

Mavrogordatos, George. "Orthodoxy and Nationalism in the Greek Case." West European Politics 26, no. 1 (2003): 117-136. doi: 10.1080/71400457110.1080/01402380412331300227.

Mazower, Mark. Salonica, City of Ghosts: Christians, Muslims and Jews 1430-1950. London: Harper Perennial, 2005.

McGuire, Valerie. "Arcadian Histories: Italian Encounters in the Eastern Mediterranean." In New Perspectives in Italian Cultural Studies. Volume I: Definition, Theory and Accepted Practices, edited by Graziella Parati, 231-258. Madison: Fairleigh Dickinson University Press, 2012.

McGuire, Valerie. "Remnants of Empire : Memory, Identity and Cultural Heritage in the Southeast Aegean." In Continuité et rupture des échanges en Méditerranée. Histoire, religion, littérature, société, edited by Jacques-Emmanuel Bernard, Nicolas Huchet, Yusuf Kocoglu, Alessandro Leiduan and Laure Lévêque, 95-109. Toulon: Université de Toulon, 2016.

Nasuhoğlu, Mehmet Sadi. Rodos: Anılar, Öyküler. Muğla: Muğla Üniversitesi Basımevi, 2004.

Nora, Pierre. "Between Memory and History: Les Lieux de Mémoire.” Representations 26 (1989): 7-24. doi: $10.2307 / 2928520$.

Orakçı, Meryem. Rodos Müslümanlart: Selam Gazetesi, 1926-1936. Istanbul: Kitap Yayınevi, 2012.

Örenç, Ali Fuat. Yakındönem tarihimizde Rodos ve Oniki Ada. Istanbul: Doğu Kütüphanesi, 2006.

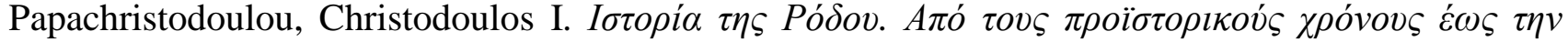
$\varepsilon v \sigma \omega \mu \alpha \dot{\tau} \omega \sigma \eta \tau \eta \varsigma \Delta \omega \delta \varepsilon \kappa \alpha ́ v \eta \sigma o v$ (1948) [History of Rhodes: From the Prehistoric Times to the Incorporation of the Dodecanese [to Greece]]. 1972. Reprint, Athens: Stegi Grammaton kai Tehnon Dodekanisou, 1994. Page references are to the 1994 edition.

Picciotto, Liliana. Il libro della memoria. Gli ebrei deportati dall'Italia, 1943-1945 [The Book of Memory. The Jews Deported from Italy, 1943-1945]. Milan: Mursia, 2002.

Pierron, Bernard. Juifs et chrétiens de la Grèce moderne: histoire des relations intercommunautaires de 1821 à 1945 [Jews and Christians in Modern Greece: a history of intercommunal relations, 1821-1945]. Paris: L’Harmattan, 1996. 
Prins, Gwyn. “Oral History.” In New Perspectives on Historical Writing, edited by Peter Burke, 120156. Philadelphia: University of Pennsylvania Press, 1992. Reprint, Philadelphia: University of Pennsylvania Press, 2011. Page references are to the 2011 edition.

Rappas, Alexis. "Insularity and Ethnicity in the Eastern Mediterranean: The Dodecanese under Italian Colonial Rule.” In Mediterràneos: An Interdisciplinary Approach to the Cultures of the Mediterranean Sea, edited by Sergio Carro Martín et al., 263-273. Newcastle-UponTyne: Cambridge Scholars Publishers, 2013.

Ricœur, Paul. La mémoire, l'histoire, l'oubli [Memory, History, Forgetting]. Paris: Seuil, 2000.

Roberts, Jo. Contested Land, Contested Memory: Israel's Jews and the Ghosts of Catastrophe. Toronto: Dundurn Press, 2013.

Rodrigue, Aron. "Introduction." In Ottoman and Turkish Jewry: Community and Leadership, edited by A. Rodrigue, ix-Xv. Bloomington: Indiana University Turkish Studies, 1992.

Rothberg, Michael. Multidirectional Memory: Remembering the Holocaust in the Age of Decolonization. Stanford: Stanford University Press, 2009.

Shachar, Nathan. The Lost Worlds of Rhodes: Greeks, Italians, Jews and Turks Between Modernity and Tradition. Brighton: Sussex Academic Press, 2013.

Sintès, Pierre. "La synagogue au musée [The synagogue at the museum]." Ethnologie française 43, no. 4 (2013): 679-690. doi: 10.3917/ethn.134.0679.

Sintès, Pierre "(Re)construire la Djuderia de Rhodes [(Re)building the Djuderia of Rhodes]." Ethnologie française 43, no. 1 (2013): 19-30. doi: 10.3917/ethn.131.0019.

Sintès, Pierre. “A qui Rhodes? Discours d'appropriation et mise en valeur touristique dans la vieille ville de Rhodes [To whom does Rhodes belong? Discourse of appropriation and touristic promotion in the old town of Rhodes]." In Tourisme et patrimoine mondial [Tourism and world heritage], edited by L. Bourdeau, M. Gravari-Barbas and M. Robinson, 183-197. Montréal: Presses Universitaires de Laval, 2012.

Sintès, Pierre. "Retrouver Rhodes [Finding back Rhodes].” Téoros 29, no. 1 (2010): 37-45.

Sintès, Pierre. "Mi akrodo de Rhodes: paroles d'une communauté juive de la Mer Egée entre mémoire et actualité [Mi akrodo de Rhodes: words of a Jewish community of the Aegean Sea between memory and topicality].” In Les échelles de la mémoire en Méditerranée (XIX ${ }^{e}-X X^{e}$ 
siècles) [The scales of memory in the Mediterranean $\left(19^{\text {th }}-20^{\text {th }} \mathrm{c}\right.$.)], edited by Maryline Crivello, 99-129. Arles: Actes Sud, 2010.

Stroebel, William. "Distancing Disaster: Trauma, Medium, and Form in the Greco-Turkish War and Population Exchange." Journal of Modern Greek Studies 32, no. 2 (2014): 253-285. doi: 10.1353/mgs.2014.0034.

Taylor, Justin. "The Ethnarch of King Aretas at Damascus. A Note on Cor. 11, 32-33." Revue Biblique 99, no. 4 (1992): 719-728.

Toynbee, Arnold. "The Ottoman Empire in World History." Proceedings of the American Philosophical Society 99, no. 3 (1955): 119-126.

Traverso, Enzo. Le passé: modes d'emploi. Histoire, mémoire, politique [The past: a manual of instruction. History, memory, politics]. Paris: La Fabrique, 2005.

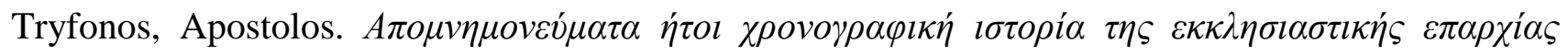

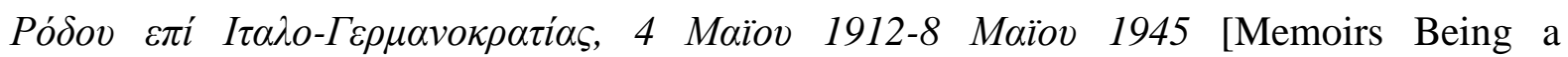
Chronological History of the Ecclesiastical Province [Diocese] of Rhodes under the ItaloGerman Occupation, 4 May 1912-8 May 1945], 2 volumes. Athens Dion: Petsali, 1947.

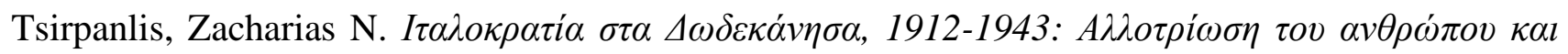

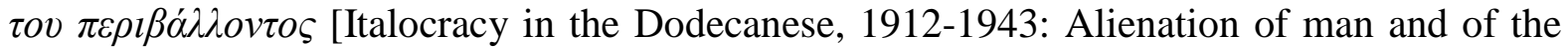
environment]. Rhodes: Zete Publications, 1998.

Üngör, Uğur Ümit. The Making of Modern Turkey: Nation and State in Eastern Anatolia, 19131950. Oxford: Oxford University Press, 2011.

Varon, Laura. The Juderia: A Holocaust Survivor's Tribute to the Jewish Community of Rhodes. Westport: Praeger, 1987.

Vatin, Nicolas. L'Ordre de Saint-Jean de Jérusalem, l'Empire ottoman et la Méditerranée orientale entre les deux sièges de Rhodes, 1480-1522 [The Order of Saint-John of Jerusalem, the Ottoman Empire and the Eastern Mediterranean between the two sieges of Rhodes, 14801522]. Paris: Peeters, 1994.

Vatin, Nicolas. “Îles grecques? Îles ottomanes? L'insertion des îles de l'Egée dans l'Empire ottoman à la fin du XVI ${ }^{\mathrm{e}}$ siècle [Greek islands? Ottoman islands? The insertion of the Aegean islands in the Ottoman Empire at the end of the $16^{\text {th }}$ c.]." In Insularités ottomanes [Ottoman 
insularities], edited by Nicolas Vatin and Gilles Veinstein, 71-89. Paris: Institut Français d'Etudes Anatoliennes and Maisonneuve \& Larose, 2004.

Zemon Davis, Natalie and Randolph Starn. "Introduction." Representations 26, no. 2, Special Issue: Memory and Counter-Memory (1989): 1-6. 